\title{
Karl Marx and the Global History of the Civil War: The Slave Movement, Working-Class Struggle, and the American State within the World Market
}

\author{
Matteo Battistini \\ University of Bologna, Department of Political and Social Sciences, \\ Associate Professor
}

\begin{abstract}
This essay stitches together the fragments of Marx's work on the United States that are scattered in newspaper articles, letters, notes, in some digressions in his early writings, in his economic manuscripts and in Capital (1867). The main aim is to show that what we can call a "global history of the Civil War" emerges from his pen: a history that is global not simply in a geographical sense, that is, because it expands the European space beyond the Atlantic and towards the Pacific, but also because of the general meaning it takes on in the history of capitalism. The essay highlights how the Civil War opened the Marxian issue of emancipation, his vision of class struggle and his view of the working class, to the presence of a black proletariat that interacted with the struggle of the white working classes, the latter of which until then had been the main focus of his work. It also highlights how the different and disarticulated voices of labor - slave and free, black and white - on both sides of the Atlantic effected a revolutionary shift in the Civil War: interjecting a "revolutionary turn" into what we can call the "long constitutional history" of the political conflict between North and South that changed the economic and social shape of the nation. More importantly, the essay reconstructs what can be termed the "state moment," which was entangled with the "long constitutional history" and the "revolutionary turn" of the Civil War. As the transnational calls for emancipation from slavery and wage labor impacted the transnational processes of accumulation of industrial capital, the American state became a player in the world market: its financial and fiscal policies became socially linked to the government of industrial capital. In this sense, as the essay underlines in the conclusion, the "global history of the Civil War" that Marx effectively drafted, outlined the theoretical and political hypothesis that formed the basis of his mature reflection in the pages of Capital: the "emancipation of labour" should be thought of as a global issue, "neither a local nor a national, but a social problem."
\end{abstract}

"In my view, the most momentous thing happening in the world today is the slave movement on the one hand, in America, started by the death of Brown, and in Russia, on the other... I have just seen in the Tribune that there's been another slave revolt in Missouri, which was put down, needless to say.

But the signal has now been given.

Should the affair grow serious by and by, what will become of Manchester?" - Marx To Engels, January 11, $1860^{1}$

International Labor and Working-Class History

No. 100, Fall 2021, pp. 158-185

(C) International Labor and Working-Class History, Inc., 2021. This is an Open Access article, distributed under the terms of the Creative Commons Attribution licence (https://creative commons.org/licenses/by/4.0/), which permits unrestricted re-use, distribution, and reproduction in any medium, provided the original work is properly cited.

doi:10.1017/S0147547921000089 


\section{Outside Historiography}

Marx's letter to Engels ten months before Lincoln's election shows how the authors of The Communist Manifesto (1848) supported the Union against the Confederacy. Marx looked at the heart of British industry and its working class while establishing the social and political centrality of slavery and the insurrection against it at that time. In this way, Marx distanced himself from what he defined as the "vulgar-democratic phraseology"2 of Atlantic liberalism: the Manchester School of free trade and laissez-faire and Henry Carey's American School of Political Economy. According to Marx, Atlantic liberalism raised the abolitionist flag of free labor against slavery only under pressure from the "slave movement" and the workers' struggle. In his view, the working-class struggles unexpectedly followed the path of the world market after the revolutionary uprising of 1848. In this sense, slave and free labor was the global point of view through which Marx read the "irrepressible conflict." 3

Unsurprisingly, then, while Marx is quoted in most of the twentieth-century historiographical works on the Civil War, his writings are considered irrelevant or not particularly significant for its historical understanding. For much of the twentieth century, in fact, historiography interpreted the Civil War in the light of the "racial pact" that in the last quarter of the nineteenth century had legitimized segregation by pacifying the North and South in the name of White America. This racial premise of the historiographical narrative must be understood within the context of the ideology of American consensus that arose at the end of the 1930s and was dominant until the 1960s. Its highest expression was the consensus school, the historiography of consensus according to which the United States, from the time of its inception, had been a middle-class society that had avoided the class struggle seen in Europe's tumultuous history. In the light of historical exceptionalism, the tragedy of the Civil War was not considered part of the historiographic narrative except as an event limited to the history of the nation: as a redemption for past faults that America had overcome in a present made of freedom and democracy, or as a unifying event that had pacified the North and the South. The Civil War was thus limited to a war of secession within the national border, where even the Black Reconstruction was long denied or was de-legitimized by the racial myth of the lost cause. ${ }^{5}$ The international context was examined only for the Union's and Confederacy's foreign policies and for Europe's attitude, particularly Britain's, toward the belligerents. ${ }^{6}$.

From the 1960s and 1970s, social history, labor history, and above all Black Studies as well as, recently, the new transnational history, have instead shifted attention to subjects and themes previously neglected. For example, the role of slaves and women in the Civil War, and that of free Blacks in the abolitionist movement; the economic nature of the sectional conflict and the financial and industrial rise of American capitalism; the historical process of state- and nation-making; and the political and social tensions that divided the North and South, the neglect of which allowed a single representation of the conflict 
between the Union and the Confederacy. ${ }^{7}$ In this way, historiography has subtracted the history of the Civil War from exceptionalism in order to place it in the broader historical, international, and transnational context that held Europe and America together: the nationalization wars that marked Europe and Latin America between 1848 and 1870, the cultural and political exchanges between the two sides of the Atlantic, and the economic processes showing that the plantation system was an integral part not only of American capitalism but of capitalism sans phrase. ${ }^{8}$

These studies therefore have the merit of having opened the Civil War to global history. ${ }^{9}$ However, they have made it difficult to identify a general meaning of the Civil War, not only for US history but also for the history of capitalism. In fact, the study of multiple subjects and themes has ended up leveling out all political and social phenomena. If consensus historiography has obscured the meaning of the war, of slavery, and of the fight against slavery in order to represent a nation united in the Cold War against Communism, then the new historiographies following the ideological and narrative fractures of the 1960s and $1970 s^{10}$ have given slavery and abolitionism an unprecedented visibility. Yet, they have highlighted above all the undisputed affirmation of capitalism and its economic, legal, and cultural institutions, or else they have analyzed a multiplicity of conflicts and tensions of race, gender, and religion between social groups and lower classes with such different interests as to impede any overall vision.

This does not in any way mean that the critical historical studies of race are an impediment to a more general interpretation of the history of Civil War. They have effectively and positively disassembled consensual (and racially connoted) generalizations of the national history by freeing forgotten voices from the archives and revealing the constructed nature of oppressive institutions and categories. However, the microhistories that have come to influence historiography particularly since the cultural turn of the 1970s often do not present an overall critical view capable of holding race and capitalism together. Thus, the fight against the "peculiar institution" seems to diminish and the abolitionist movement to be further downsized. ${ }^{11}$ Furthermore, the role of wage labor, which Marx considered "the true political power of the North," appears to be weakened. ${ }^{12}$ The New York Times 1619 Project released in August 2019 is illustrative. It reframes US history for the non-expert public by placing slavery and race at the center of national history. However, when the project addresses capitalism showing its strong connection with slavery, it does not discuss the historical role that slave and free labor played within the history of Civil War. Even the controversy among the historians that followed the project remains limited to the unresolved debate on the origin, development, and fulfillment of the democratic ideal of the nation. ${ }^{13}$

In this sense, the history of the Civil War risks slipping back into the national narrative of the liberal triumph of free labor, even though the economic and social transformations following the Civil War had denied Lincoln's democratic ideal of "self-rule" and the "harmony of interests," which Carey had used to describe a society different from the European one because it was not marked 
by the "antagonism between capitalist and laborer."14 Marx felt that both the president who put an end to slavery and the Republican party's political economist had hidden a specific historical form of class struggle behind the ideology of free labor. That is, the class struggle that saw millions of individuals emancipating themselves from "wage slavery" by migrating West. As we shall see, Marx did not spare criticism for the founder of the American School of Political Economy. In his opinion, Carey was aiming to accommodate slavery within the harmony of society by identifying the causes of secession in the British policies of free trade that had forced the South to expand slavery, in the subsequent political clash over the customs tariff between the protectionist North and the free-trade South, and in the relative constitutional controversy that contrasted the doctrine of state rights with the sovereignty of the Union. Marx did not skimp on criticism of the president either, although he hid his criticism behind praise of the democratic character of the new world:

Lincoln is not the product of a popular revolution. This plebeian, who worked his way up from stone-breaker to Senator in Illinois, without intellectual brilliance, without a particularly outstanding character, without exceptional importancean average person of good will, was placed at the top by the interplay of the forces of universal suffrage unaware of the great issues at stake. The new world has never achieved a greater triumph than by this demonstration that, given its political and social organization, ordinary people of good will can accomplish feats which only heroes could accomplish in the old world! ${ }^{15}$

We can therefore understand why in the historiography of the Civil War Marx appears as someone who has to be cited, but who is irrelevant or not particularly significant for the historical understanding of the Civil War. Marx has in fact been accused of having given in to liberalism in order to support the Union. ${ }^{16}$ Moreover, although his work on the United States has contributed to the development of new historiographies of the Civil War, his influence is not considered direct, but instead as coming via W.E.B. Du Bois's pioneering study Black Reconstruction (1935). Marx's writings on the Civil War and slavery, on the American state and capitalism have not been explicitly used or deeply discussed by the new historiographies on the Civil War. ${ }^{17}$

In fact, the fragmented and dispersed body of his work on the United States has not yet been assembled into an overall and exhaustive volume showing its historical value for the interpretation of the Civil War. ${ }^{18}$ Marx's writings on the Civil War only started attracting significant attention during the 1930s. W. E.B. Du Bois, C.L.R. James, and Raya Dunayevskaya explored them in order to establish the centrality of slavery and racism - and the "Negro's revolutionary history" against slavery and racism - in the history of the Civil War as well as in American history and politics in general. ${ }^{19}$ In particular, Du Bois intensified his study of Marx during the Great Depression with the precise aim of explicitly linking capitalism with race. In 1934, he held a course at the University of Atlanta dedicated to "Karl Marx and the Negro," but already in 1931, in an 
article published in The Crisis, he placed the "Negro problem" in the world-wide "organization of industry for private profit and control of government by concentrated wealth," by recalling what Marx had written in his 1886 famous letter to François Lafargue, and repeated in Capital:

Until the colored man, yellow, red, brown, and black, becomes free, articulate, intelligent and the receiver of a decent income, white capital will use the profit derived from his degradation to keep white labor in chains. ${ }^{20}$

As a result of his Marxian studies, in Black Reconstruction, Du Bois used the category of the proletariat to emphasize the role of blacks (both free and enslaved) in the abolition of slavery. More importantly, he employed Marx's notion of "dictatorship of the proletariat" to bring into the open the repressed experience of black reconstruction and its end in the racial pact. In this way, Du Bois became close to the US Communist party, whose publishing house issued a selection of Marx's writings on the Civil War in 1937. But there were not many other editions during the twentieth century. Only recently, on the occasion of the anniversaries of the Civil War and the birth of Marx, the publication of new anthologies and selections of writings has turned the lights of history onto the dialogue between Lincoln and Marx. Highlighting their political and historical divergences and convergences on the Civil War, slavery and free labor has allowed historiography to reaffirm the centrality of slaves in the revolt against slavery during the Civil War. ${ }^{21}$

In the light of this renewed interest, this essay stitches together the fragments of Marx's work on the United States that are scattered in newspaper articles, letters, notes, in some digressions in his early writings, in his economic manuscripts, and in Capital (1867). The main aim is to show that what we can call a global history of the Civil War emerges from his pen: a history that is global not simply in a geographical sense, that is, because it expands the European space beyond the Atlantic and toward the Pacific, but also because of the general meaning it takes on in the history of capitalism. The essay shows how the Civil War opened the Marxian issue of emancipation, his vision of class struggle, and his view of the working class, to the presence of a Black proletariat. Marx did not use the notion of Black proletariat, which was instead central to Du Bois. As we shall see, Marx used the words "negros," "slaves" or "black slaves," "fugitive slaves" or "fugitives," "black men" or "free blacks" in order to distinguish their racial and legal standing in society and to indicate their political role at different moments of the Civil War. Thus, we can use the notion of the Black proletariat as a synthesis that brings together both the social position and the historical agency of the Blacks in the struggle for emancipation. Although not present in Marx's writings, the notion of a Black proletariat provides a compass with which to orient ourselves within his work. This notion also points to a change in Marx's perspective, showing how the Civil War broadened his critical science of capital beyond the viewpoint of the working classes in Europe. In this specific sense, the Civil War opened the Marxian issue of emancipation to the presence of a Black 
proletariat that interacted with the struggle of the white working classes, the latter of which until then had been the main focus of his work. ${ }^{22}$

In this regard, the essay is indebted to the latest Marxist literature that has discussed the relationship between capitalism and race in Marx's thought. In particular, Kevin Anderson has emphasized the "intersection" of class and race that characterizes Marx's writings on the Civil War. David Roediger has argued that Marx clearly identified "the movement of slaves - not the election of Lincoln - as key impulse toward freedom," despite Marx's lack of attention to the African American struggles during the Reconstruction. Cedric Robinson has highlighted how Marx pointed out the structural relationship between slave labor and the making of industrial capital, in spite of Marx's faulty understanding of the historical role of race in Western development. Keeping in mind these varying interpretations, this essay reads Marx's writings on the Civil War in relation with his critique of political economy: The Civil War fixed the viewpoint through which Marx viewed the American state and capitalism in the framework of the world market. From this standpoint, in his fragmented work on the United States, the history of Civil War comes to light as global history of Civil War in which the interplay between class and race emerges as both an instrument of government of the industrial capital and an essential issue for the emancipation of labor. ${ }^{23}$

By concentrating mainly on his articles on the Civil War published in The New York Daily Tribune and in the Viennese Die Press, this essay highlights how the different and disarticulated voices of labor - slave and free, black and white - on both sides of the Atlantic effected a revolutionary shift in the Civil War: interjecting a revolutionary turn into what we can call the long constitutional history of the political conflict between the North and the South that changed the economic and social shape of the nation. More importantly, by critically analyzing some passages from his Economic Manuscripts of 1857-1858 and Capital, the essay reconstructs what can be termed the state moment, which was entangled with the long constitutional history and the revolutionary turn of the Civil War. As the transnational calls for emancipation from slavery and wage labor impacted the processes of accumulation of industrial capital, the American state became a player in the world market: its financial and fiscal policies became socially linked to the government of industrial capital. In this sense, as we shall see in the conclusion, the global history of the Civil War that Marx effectively drafted, outlined the theoretical and political hypothesis that formed the basis of his mature reflection in the pages of Capital: the "emancipation of labor" should be thought of as a global issue, "neither a local nor a national, but a social problem." 24

\section{Inside Global History}

Crossing the national borders, the new historiographies of the Civil War have sedimented multiple layers of meaning - transnational and global, social and political-that provide fertile ground for reading Marx. His work on the 
United States does not simply present a national history of Civil War as a secession war or sectional conflict. It does not even address international policies alone, particularly British. Rather it addresses the Civil War within the world market, the latter of which is discussed in The German Ideology (1845). This emerges first of all from the Marxian notion of slavery. Although it is not present in any relevant way in either his Communist Manifesto nor his political histories of The Class Struggle in France (1850) and other workers' struggles in Europe, the notion of slavery was already central in The Poverty of Philosophy (1847):

Direct slavery is just as much the pivot of bourgeois industry as machinery, credits, etc. Without slavery you have no cotton; without cotton you have no modern industry. It is slavery that gave the colonies their value; it is the colonies that created world trade, and it is world trade that is the precondition of large-scale industry. Thus, slavery is an economic category of the greatest importance. ${ }^{25}$

From this point of view, according to Marx, the South was not an archaic entity opposed to European civilization. On the contrary, as a cotton producer, the South was not only an integral part of the national economy, it was also a historical pillar of the world market. Slavery acquired its modern character of oppression and exploitation exclusively through the industrial capital that dominated the world market. Therefore, even if slavery "[is] incompatible with and disappears as a result of the development of bourgeois society," it "implies wage labor." Even more important was the conclusion that Marx drew from the economic historicity of slavery: Since "a negro (a man of the black race) is a negro" and "he only becomes a slave in certain relations," slavery is a "purely industrial" institution. ${ }^{26}$ In the third book of Capital, Marx wrote:

The supervision work necessarily arises in all modes of production based on the antithesis between the laborer, as the direct producer, and the owner of the means of production. The greater this antithesis, the greater the role played by supervision. Hence it reaches its peak in the slave system. ${ }^{27}$

Furthermore, it is important to underline that the historical link Marx traced between the conditions of slave and free labor echoed the workers' discourse on wage slavery that had circulated on both sides of the Atlantic from the 1830s and 1840s until the Civil War:

As long as the English cotton manufactures depended on slave-grown cotton, it could be truthfully asserted that they rested on a twofold slavery, the indirect slavery of the white man in England and the direct slavery of the black men on the other side of the Atlantic. ${ }^{28}$

On this theoretical and historical basis, as Marx observed in his notes on the writings of the British abolitionist Thomas Buxton, ${ }^{29}$ slavery and the fight against slavery immediately assumed a global meaning in the history of 
capitalism. From the beginning of the Civil War, Marx grasped the industrial repercussions of the slave revolt and military conflict, especially with regards to the Northern naval blockade of the South, the so-called Anaconda Plan. He also emphasized the political role that the working classes in Europe, particularly in Great Britain, played in publicly affirming an abolitionist position that blocked the possible interventionist policy of the European states, again particularly that of Great Britain:

It ought never to be forgotten in the United States that at least the working classes of England, from the commencement to the termination of the difficulty, have never forsaken them. To them it was due that, despite the poisonous stimulants daily administered by a venal and reckless press, not one single public war meeting could be held in the United Kingdom. ${ }^{30}$

Finally, because of the global meaning that slavery had assumed in the world market of industrial capital, Marx identified that democracy was at stake in the war against slavery, not merely as a contingent conquest in the United States but as a universal horizon at which the working classes in Europe also aimed:

The first grand war of contemporaneous history is the American war. The peoples of Europe know that the Southern slaveocracy commenced that war with the declaration that the continuance of slaveocracy was no longer compatible with the continuance of the Union. Consequently, the people of Europe know that a fight for the continuance of the Union is a fight against the continuance of the slaveocracy - that in this contest the highest form of popular self-government till now realized is giving battle to the meanest and most shameless form of man's enslaving recorded in the annals of history. ${ }^{31}$

In this sense the Civil War marked the final stage in the historical process of democratization that Marx had followed and analyzed in his writings. From the democratization of the United States discussed in On The Jewish Question (1844) and the European revolutionary uprisings of 1848 to British Chartism and the US Civil War, he considered democracy as a political movement not immediately reducible to a form of government. If Capital shifted his criticism from the political history of class struggles to the study of political economy as a capitalistic science of governance in the face of the unruly presence of the working class, if the Paris Commune (1871) excluded the prospect of the reform of the state from Marxian politics, then during the Civil War democracy was still the polemical notion of his initial philosophical reflection (Critique of Hegel's Philosophy of Right, 1844): the ruthless criticism of democracy as "bourgeois democracy" did not remove the possibility of its partisan appropriation. In other words, democracy still defined a field of struggle that established the conditions for the possible emancipation from slavery and wage labor. ${ }^{32}$ 
For Marx, then, the history of the Civil War was global history first of all because it opened the issue of emancipation to the presence of a Black proletariat fighting against slavery, a presence that interacted with the European working-class movement within the world market of industrial capital. Marx did not consider slavery as an endangered past in a present that would be freed from the pre-capitalist chains of command. On the contrary, for him, slavery was an anachronism that marked the present: slavery negatively affected the possibilities of emancipation because, by holding together property and race in a "peculiar institution," it rewarded the separation of labor from property with racial superiority. In this specific sense, slavery would have survived its abolition as a "color line" that divided labor into black and white skin. ${ }^{33}$ This was exactly why, even after the Civil War, Marx chose to use the notion of emancipation again after it had been shelved in 1848. As we shall see, in light of the "slave movement," Marx removed emancipation from the historical indeterminacy of his youthful humanism and turned it into a political notion that reflected the heterogenous, transnational-not national-composition of the working class. That is, emancipation encompassed and indicated the political connection between the different and disarticulated voices of labor-slave and free, black and white - that rejected the position assigned to them by industrial capital in the world market. ${ }^{34}$

\section{The Long Constitutional History of the Civil War}

Marx's work on the Civil War is composed mainly of the writings that he published in 1861 and 1862, in The New York Daily Tribune and in Die Presse, and of the correspondence that he kept up above all, but not only, with Engels until the end of the 1870s. His information came from literature and from the British and American, Unionist and Confederate press, which he presumably consulted from the shelves of the British Library. Equally important is his correspondence with German militants, even though it became intermittent or stopped altogether during the war years. They emigrated to the United States after the defeat of 1848, and supported the Republican party from an antislavery point of view. Among them, the most important was Joseph Weydemeyer, the founder of the Amerikanische Arbeitersbund (1853), a league in Chicago open to all workers without distinction of color or sex. Weydemeyer fought in the Union army together with two other German members of the Communist League, August Willich and Fritz Anneke. ${ }^{35}$

The collaboration with the most widespread US newspaper of the time, which had about two hundred thousand subscribers and one million readers, began in 1851, following a meeting with Charles Dana-the newspaper's editor-in Cologne during the revolutionary uprisings of 1848. Designed to inform the public about European politics, the writings were interrupted in the first year of the war for various reasons, such as payment was not regular and the articles were often cut, modified, or published without accreditation. Moreover, thanks to Carey, the newspaper became the republican voice of 
the American industrial capital in a war that was also fought to defend US manufacture from British trade competition. ${ }^{36}$ The articles that Marx published from October 1861 to February 1862 dealt with the war in an international key, giving an account of the British (and not only) attitude toward the belligerents. Nevertheless, they anticipated themes that were taken up again in the following months: criticism of the interpretation that The Times, The Economist, and other British liberal press presented of the Civil War as a conflict on the customs tariff triggered by the "Northern lust for sovereignty;" 37 condemnation of the interests in cotton that pushed the British government to choose neutrality and the British industrial capital to increase the production of cotton in India; the workers' support of the Unionist cause despite the employment crisis caused by the collapse of textile production. ${ }^{38}$

In the writings published in Die Presse, this international and transnational framework was built up further in terms of a long constitutional history, from the founding of the republic to the secession. Marx examined the series of compromises on slavery that began with the Continental Congress and continued with the expansion to the West, the federal laws (the Fugitive Slave Act of 1850 and the Kansas Nebraska Act of 1854), and the ruling of the Supreme Court (Dred Scott of 1857) that made the Union a "slave" of the South, constitutionalizing slavery as a "guiding star . . . in the foreign, as in the domestic, policy of the United States." Within this constitutional history, Marx reconstructed the formation of the Republican party in the years of guerrilla warfare in Kansas and evidenced the discord within a Democratic party embodied by Senator Stephen Douglas (Illinois), who defeated Lincoln in the election for the Senate in 1858. Moreover, Marx discussed the Republican platform in the presidential elections of 1856 and 1860, underlining "its principal contents," that is, "not a foot of fresh territory is further conceded to slavery." Above all, behind the constitutional history that led to Lincoln's presidency, Marx saw a social process that transformed the political conflict between the North and the South into a Civil War, moving the issue of slavery from constitutional compromise to a conflict that affected society:

The present struggle between the South and North is, therefore, nothing but a struggle between two social systems, the system of slavery and the system of free labor. The struggle has broken out because the two systems can no longer live peacefully side by side on the North American continent. It can only be ended by the victory of one system or the other. ${ }^{39}$

As historiography has shown, his historical reconstruction was not without errors. Marx overestimated or underestimated the military forces in the field and the popular support for the Unionist and Confederate causes. ${ }^{40}$ However, what is important to emphasize are the different temporalities-institutional and social-that Marx highlighted in his constitutional history of the Civil War. That is the key in which we should read the pages he dedicated to the economic and demographic transformations that affected the South and the North, 
fragmenting the two sides along class and race lines that prevented their representation in terms of people or nation. In his view, the political expansion of the plantation system and the associated drafting of the slave constitutions of the South states were linked to the peculiar social process of concentration and separation of property from labor that made the capitalist and the landowner coincide in the person of the slaveowner. Since "the business in which slaves are used is conducted by capitalists," these latter apply the "maxim of slave management," namely that "the most effective economy is that which takes out of the human chattel in the shortest space of time the utmost amount of exertion it is capable of putting forth." 41 Consequently, the conquest of ever new land to make cotton, tobacco, and sugar plantations productive and to stake a claim in the federal government through Senate control, did not result in a distribution of slavery as property but in its accumulation in the hands of "the oligarchy of the 300,000 slave lords in the South vis-à-vis the five million whites." The resulting separation of free labor from slave labor, which implied "the rapid transformation of states like Maryland and Virginia ... into states which raises slaves to export into the deep South," left no alternative. As Marx noted, quoting a speech by Senator Robert Toombs, Georgia's delegate to Montgomery's secessionist Convention (February 1861) and Secretary of State of the Confederacy: "in fifteen years without a great increase in slave territory, either the slaves must be permitted to flee from the whites, or the whites must flee from the slaves." 42

The slave oligarchy therefore asserted its right to "concentration, status, and resources" and to "put down any opposition," thus imposing secession as "usurpation." With the exception of South Carolina, which had in John C. Calhoun the founding father of secession, "everywhere ... there was the strongest opposition to secession." In some letters to Engels, Marx reported a series of titles and quotations from various newspapers in the South-The Augusta Chronicle and Sentinel and The Macon Journal from Georgia, The Mobile Advertiser and The North Alabamian from Alabama, and the New Orleans True Delta from Mississippi-that exposed how secession had taken place "without the authority of the people." Through a "coup de main" and "invalid act" in the legislative assemblies or through elections of special conventions that were held in "a reign of terrorism," exercised through "the mob" of "poor whites" that were moved like "Zouaves" in defense of racial superiority and the slaveowner's property: ${ }^{43}$

Only by acquisition and the prospect of acquisition of new Territories . . . is it possible to square the interests of these "poor whites" with those of the slaveholders, to give their restless thirst for action a harmless direction and to tame them with the prospect of one day becoming slaveholders themselves. ${ }^{44}$

Marx therefore did not consider any Southern state to be an "actual slave state" because the slaveowner's enterprise was conducted in a capitalist manner and because the racial line along which production was organized reinforced the separation of property from labor. With greater reason, therefore, the border states 
were not slave states either, not even those belonging to the Confederacy, because there the slave system and free labor struggled openly to gain the upper hand. Thus "the South" was not "a territory closely sealed off from the North geographically," and neither could it be represented in a people or a nation. It did not constitute a "moral unity," but rather a "battle-cry" that existed exclusively by "subjugating completely . . . the section of the white population that had still preserved some independence under the protection of the democratic Constitution of the Union." Marx noted that "between 1856 and 1860 the political spokesmen, jurists, moralists and theologians of the slaveholders' party had already sought to prove, not so much that Negro slavery is justified, but rather that color is a matter of indifference and the working class is everywhere born to slavery." In the event of a Confederate victory, the prospect for all labor - black and white - was therefore "a reorganization of [the Union] on the basis of slavery:"

The slave system would infect the whole Union. In the Northern states, where Negro slavery is in practice impossible, the white working class would gradually be forced down to the level of helotry. This would fully accord with the loudly proclaimed principle that only certain races are capable of freedom, and as the actual labor is the lot of the Negro in the South, so in the North it is the lot of the German and the Irishman, or their direct descendants. ${ }^{45}$

\section{The Revolutionary Turn}

Marx exalted the political rejection of the historical perspective of a "slave republic" entangled in the long constitutional history. In his writings, he highlighted the revolutionary turn of the Civil War that broke "the general formula of the United States history": the "progressive abuse of the Union by the slave power, working through its alliance with the Northern Democratic party." 46 In his historical reconstruction, the tensions between the different institutional and social temporalities of the Civil War erupted under the pressure of the distant and disarticulated voices of individuals working as slaves and freemen. For Marx, the Civil War was a social and political struggle that was not national but global due to the meaning that slavery had assumed in the world market of industrial capital. The transnational process of exploitation and accumulation through this peculiar institution was overturned by the interrelated agency of the "slave movement," of the "public opinion" of the working classes in Great Britain and the "political power" of free and waged labor in New England and in the Northwest of the United States. Their claims to emancipation made "all compromise impossible" 47 because they prevented the war from being kept within its institutional temporality: It would not have been possible to save the democratic Constitution of the Union without abolishing slavery. This was the passage from "the constitutional waging of war" to "the revolutionary waging of war," a historically contingent moment that found its maximum expression in the Emancipation Proclamation (January 1, 1863), 
but within which long-term labor action-slave and free-affected the outcome of the war. ${ }^{48}$

For Marx, the "slave movement" during the Civil War was mainly a mass flight from the plantations. What Du Bois called a "general strike" 49 forced "a large section of the slaveholders, with their black chattels," to "constantly migrate to the South, in order to bring their property to a place of safety." Consequently, "the war itself brought about a solution by radically changing the form of society in the border states." What Weydemeyer-engaged during the war as a lieutenant and colonel in various battles in Missouri, Arkansans, Kentucky, and Tennessee-defined as an "exodus," comparable to the Irish one following the potato famine, left behind "encroachments of . . . free labor." 50 Moreover, it created much tension within the Union army. Constantly informed by Engels on the events of the war, Marx wrote about this from November 1861 to the summer of 1862, reporting on the insubordination of generals and lieutenants. They enlisted the fugitive slaves as free men, violating the laws on black smuggling (Confiscation Act of 1861 and 1862), which led to their progressive revision until the drafting of the Proclamation. They also intervened publicly in favor of the abolition of slavery. From Marx's pen it emerged, therefore, how the military insubordination moved Lincoln and his Secretary of State William H. Seward away from an initial moderate and constitutional management of the war, as exemplified by the dismissal of the abolitionist General John C. Frémont from the post of commander of the district of Missouri over his emancipation edict in St. Louis. They were also forced to limit and finally dismiss General George McClellan who, on the strategic front of the Potomac River, aimed for agreements "with constant regard to the restoration of the Union on its old basis." The mass flight of slaves therefore freed the president from the political problem of "keeping the loyal slaveholders of the border states in good humor" - a problem that "has smitten the Union government with incurable weakness since the beginning of the war, driven it to half measures, forced it to dissemble away the principle of the war, and to spare the foe's most vulnerable spot, the root of the evil, slavery itself." As a result, war should no longer be waged "in a strictly businesslike fashion"; instead the "revolutionary tendencies" that affected the peculiar institution needed to be recognized. For Marx, therefore, it was the "slave movement" and not the "legally cautious, constitutionally conciliatory" Lincoln that affirmed "the battle-slogan of Abolition of Slavery." 51

To the ears of the president and his administration this outcry was intensified by the "chorus" that arose overseas against possible British recognition of the Confederacy and the consequent possible military intervention of the Palmerston government. Between the end of 1861 and the summer of 1862 , Marx alternated discussion of the US theatre with a reconstruction of the British antiwar movement. From the Trent case onward-where a Union vessel arrested two Confederate ambassadors from a British ship-Marx underlined how "the issue between the English people and the English Cabinet" imposed an "anti-intervention feeling," which Palmerston and the press soon 
took note of. More importantly, Marx pointed out that popular opinion of "all sections of the English people," with the exception of "the friends of cotton," began to look like a working-class public opinion against slavery. The mass presence of workers placed a different political slant on the antiwar movement. While at the heart of people's opinion was simply support of the North against the "anti-Republican war," in the workers' assemblies this democratic vision became "the policy of the working class." Once again, after the Reform Bill of 1832, the abolition of the protectionist laws on wheat and the law establishing the ten-hour day, the working class imposed its will on the government, even without being represented in Parliament: Workers organized these protest actions and influenced events at a time when even adult male workers did not enjoy the suffrage, still based upon heavy property qualifications. Already in February 1862, Marx paid tribute "to the sound attitude of the British working classes, the more so when contrasted with the hypocritical, bullying, cowardly, and stupid conduct of the official and well-to-do John Bull." The danger of "an English war for the slaveocrats" was averted when, on the stage of public opinion, the abstractness of the people left room for the materiality of the working class, denoting with the abolition of slavery an essential moment in the emancipation from wage labor. For Marx, a mass of migrants (mostly Irishmen and Britons) had in fact escaped and were still escaping from the European regime of wage slavery and finding "a new home in the United States." 52

The voices of the black proletariat fleeing from plantations and of the working classes striking against slavery in Great Britain that Marx politically connected within the industrial course of the world market, reached its highest note when the free labor composite - that is the self-working farmers of the Northwest and the working classes of New England-burst onto the scene, thus interrupting the institutional temporality of the long constitutional history. In a letter to Engels dated July 1861, Marx identified "the extraordinary development of the North Western states . . . with [their] rich admixture of newly-arrived Germans and Englishmen" as the long-term process that shattered the constitutional compromise by providing electoral bulk to the Republican party. Moreover, in August 1862, in two contributions to Die Presse preceding the October one on the Preliminary Proclamation, Marx focused on the abolitionist movement, reporting the speech that Wendell Philips - "the leader of the Abolitionists in New England" together with William Lloyd Garrison and Gerrit Smith - gave in Abington, Massachusetts, on the anniversary of the emancipation of slaves in the British West Indies. Above all, Marx emphasized that abolitionism was rooted in the "popular classes" of New England and the Northwest that constituted "the main body of the army," together with the "considerable amount of people of military experience who had immigrated to the United States in consequence of the European revolutionary unrest of 1848-49." These masses "did not, of course, lend [themselves] so readily to intimidation as the gentlemen of Wall Street" who had invested in the plantation system. These masses built up "a power that was not inclined either by tradition, temperament or mode of life to let 
[them] be dragged from compromise to compromise in the manner of the old Northeastern states." They were "determined to force on the government a revolutionary kind of warfare and to inscribe the battle-slogan of Abolition of Slavery! on the star-spangled banner." For them, the defeat of the South and the end of the plantation slave system opened the way to realizing a historical workers' claim: the distribution of land to the West, which Lincoln conceded with the Homestead Act (May 1862)..$^{53}$

The revolutionary turn imposed by the "slave movement," the "policy of the British working classes," and the "political power" of free and waged labor in New England and the Northwest therefore shifted the war in the direction of abolitionism, impacting the cautious constitutional conduct of the president who was thus forced "to act the lion." In the autumn of 1862 , even more important than the Union's victories on the war front and the "symptoms of Disintegration in the Southern Confederacy" was the announcement of the Emancipation Proclamation (January 1, 1863). Although the Proclamation did not affect the owner's right to slavery in border states and states occupied by the Union army, it affected some three million slaves outside the territory controlled by the Union. For Marx, it was therefore a turning point, a "tearing up of the old American Constitution": Although the decree was written as an "actiones juris," as "routine summonses sent by a lawyer to the lawyer of the opposing party, legal chicaneries," it nevertheless represented "the most important document in American history since the establishment of the Union ... the manifesto abolishing slavery." ${ }^{54}$

Marx knew that the manifesto would encounter several setbacks, both in the military and in the political sphere. He believed that it would be necessary to fight slavery for a long time to come. The reaction that the announcement of the Proclamation provoked in the congressional elections of November 1862, when the Republican administration suffered a defeat in favor of the Democratic party, did not constitute a mere electoral event. It was rather a sign of how slavery would survive its very abolition, along color lines that pushed the white and immigrant workers to see in the Black proletariat "a symbol of slavery and the humiliation of the working class." 55 Yet, unlike Engels and despite the controversial events of the war, Marx was already convinced that the Proclamation would determine the outcome of the war. Two years after the conclusion of his collaboration with the Viennese newspaper, his laborious political work of weaving the fabric of the transnational connection between the different and disarticulated voices of Black and white labor went public. The "Address to Abraham Lincoln" of the International Working Men's Association (December 23, 1864), which Marx surely drafted, publicly welcomed his re-election. The letter published in The Bee-Hive Newspaper (November 7, 1865) declared his global view of the Civil War and the political meaning the Civil War had in the world market of industrial capital:

From the commencement of the Titanic-American strife the working men of Europe felt instinctively that the star-spangled banner carried the destiny of 
their class. The contest for the territories which opened the dire epopee, was it not to decide whether the virgin soil of immense tracts should be wedded to the labor of the emigrant, or prostituted by the tramp of the slave-driver?

... the working classes of Europe understood at once, even before the fanatic partisanship of the upper classes for the Confederate gentry had its dismal warning, that the slave-holders' rebellion was to sound the tocsin for a general holy crusade of property against labor, and that for the men of labor, with their hopes for the future, even their past conquests were at stake in that tremendous conflict on the other side of the Atlantic.

... While the working men, the true political power of the North, allowed slavery to defile their own republic; while before the Negro, mastered and sold without his concurrence, they boasted it the highest prerogative of the whiteskinned laborer to sell himself and choose his own master; they were unable to attain the true freedom of labor or to support their European brethren in their struggle for emancipation, but this barrier to progress has been swept off by the red sea of Civil War.

The working men of Europe feel sure that, as the American War of Independence initiated a new era of ascendancy for the middle class, so the American Anti-Slavery War will do for the working classes.

The message was signed by a number of militants, not just British, of the International Workingmen's Association who helped to organize the workers' chorus against slavery. And, according to Marx, it left no room for the "vulgar-democratic phraseology" of Atlantic liberalism. The "great Democratic Republic," which a century earlier had given the "first impulse ... to the European revolution," was not the purifying outcome of the Civil War that brought the "American" people back to their original unity. Marx did not reduce the Civil War to the liberal triumph of free labor, which should have concluded the democratic movement begun in 1776. To him the slave-free democracy of the Thirteenth Constitutional Amendment appeared rather as a partisan conquest that revealed what the color line, the racial privilege of white labor, hid behind the doctrine of free labor: "the great problem of the relation of labor to capital." Marx reacted with satisfaction to the words with which Lincoln had responded to the message from the International Workingmen's Association: "you can understand [he wrote to Engels] how gratifying that has been for our people." But, for him, the answer reaffirmed the president's constitutional vision. While Lincoln was convinced that the nation would emerge from the Civil War by renewing the promises of self-rule and happiness that had marked his personal and political biography in the pre-war Northwest, for Marx those promises were closed off by the war. ${ }^{56}$ Not only because Marx was soon irritated by the turn of events with the murder of Lincoln and the reactionary politics of his successor Johnson, ${ }^{57}$ but also because, although stripped of slavery, the West would no longer be the space in which US and immigrant workers found their emancipation from wage slavery. In Capital, the global history of Civil War was described using this historical and theoretical 
meaning. The abolition of slavery as an institution (probably the biggest expropriation of private property since the land distribution in the French Revolution) and the subsequent conquest of black male suffrage saturated the historical movement of democracy, determining not only new social relations but also new political conditions that offered the possibility for emancipation. This emerged in what we can call the state moment of the Civil War by analyzing some passages on the United States scattered throughout Marx's work.

\section{The State Moment}

In his correspondence with Engels, Marx captured in the events following the assassination of Lincoln the origins of the racial pact that had moved the history of the United States toward segregation. However, he did not pay attention to the black reconstruction that Du Bois brought to light in continuity with his work on the United States. The political challenge of the "arduous work of political reconstruction and social regeneration" which Marx alluded in the International Workingmen's Association message to Lincoln and in the International's address to Johnson, but which he did not pursue in the decade following the end of the war. Instead, his attention was primarily focused on the historical and theoretical understanding of the new social relations and political conditions that the Civil War had determined within the world market. In this sense, the racial pact that Marx could only presage was relevant for concluding his global history of the Civil War. It constituted the guise under which the economic and political independence of the nation found fulfillment: the "Yankees" finally stripped off the dirty clothes of the colonial past and put on the democratic attire through which the "middle-class revolution" was realized after a century. ${ }^{59}$ If the United States was still to be considered as a "European colony" before the Civil War because its "economic development" was "a product of Europe, more especially of English modern industry," the Civil War severed that colonial dependence. It realized the historical, institutional, and social process of the financial construction of the American state and the industrial transition to capitalism that was not accomplished with the War of Independence. For Marx, this was the state moment of the Civil War. The institutional tension between state rights and the sovereignty of the Union bequeathed by the founding fathers not only did not permit the "slave revolution" to be avoided, but in the uncertain pre-war constitutional framework it did not allow capital to find its established social form in industrial capital either. In the so-called early republic, society still defined an economically indeterminate space, where the glorious narrative of the British and US political economy that elevated Robinson Crusoe to the leading role in the history of capitalism was continually upended in misadventures of capital. As Marx underlined when discussing the British imperial experience overseas in the chapter "The Modern Theory of Colonization" in the first book of Capital, the historical process of capital accumulation failed to reach its established European form overseas. ${ }^{61}$ 
In some letters where Marx discussed the economic measures, in particular the huge print-run of paper money that the Union adopted to finance the war, the state moment of the Civil War thus emerged as a solution to the colonial problem of accumulation. Unlike Engels, who saw "the financial crash" approaching, Marx did not believe in the bankruptcy of the Union: "the United States know from the time of the War of Independence . . . how far one may go with depreciated paper money." For Marx, the issue of the first national single banknote - the greenback - and its diffusion in substitution of the bonds of the slave states' banks were the economic sign of the "confidence in them [yankees] and hence in their government [Union]." Moreover, the depreciation of paper money and the consequent increase in interest on public debt were balanced by an increase in exports and a trade balance favored by protectionist policies. Most importantly, the "new system of taxation" that integrated the customs tax (Morril Act of 1861) with direct and indirect taxation (Revenue Act of 1862) guaranteed a "reflux" of paper money that counterweighed devaluation. For Marx, "the inherent disadvantage of the thing" was rather the "premium for jobbing and speculation" of the capitalist who had invested in public debt. ${ }^{62}$

What Engels saw as an unscrupulous financial policy therefore hid a process of accumulation that, in the chapter of Capital on "The so-called Primitive Accumulation," Marx did not confine to the circumstance of war, but rather framed within the long period, that began with the discovery of the Americas, during which the European states - the United States among them - acted through public debt as agents of industrial capital in the world market:

National debts, i. e., the alienation of the state-whether despotic, constitutional or republican-marked with its stamp the capitalistic era ... With the national debt arose an international credit system, which often conceals one of the sources of primitive accumulation in this or that people . . By the beginning of the 18 th century . . . Holland had ceased to be the nation preponderant in commerce and industry. One of its main lines of business, therefore, from 17011776 , is the lending out of enormous amounts of capital, especially to its great rival England. The same thing is going on today between England and the United States. A great deal of capital which appears today in the United States without any certificate of birth, was yesterday, in England, the capitalized blood of children. ${ }^{63}$

The state moment of the Civil War condensed the historical event of the European states overseas, establishing a centralized system of public debt that was fed by modern fiscality, based on indirect taxation and ensured by the protectionist system that capitalized the national means of production. After the Glorious Revolution of 1688, which had inaugurated the commercial wars between the European powers, the British state systematically combined colonial policy with public debt, taxation, and protectionism "to hasten, hothouse fashion, the process of transformation of the feudal mode of production into 
the capitalist mode, and to shorten the transition." In the same way, the Civil War completed the financial construction of the American state, declaring the War of Independence economically concluded: the Union concentrated and organized the "force of society" conferring on the state "the power . . . to shorten [the] genesis of the industrial capital." 64

What we have defined with Marx as the constitutional history, the revolutionary turn, and the state moment of the Civil War do not therefore determine a chronological sequence, but rather indicate a contemporaneity of temporalities-institutional and social-that synchronized the national history of the United States with the world market. In this sense, the Civil War imposed a double global twist on the making of the American state: while the Civil War institutionalized democracy as the established form of government by removing its historical movement from the claims of emancipation by black and white workers, it also transformed the American state into a player in the world market. Its politics and policies were socially linked to the government of industrial capital. In this way, what Marx defined as an "artificial product of modern society," or rather, "the process of separation between laborers and conditions of labor," which transformed "the mass of the population into wage laborers, into free laboring poor," found its fulfillment also on the Western shores of the Atlantic. The irony of history was that it was those who in 1776 had renounced Britishness that realized the English "modern theory of colonization," or rather, the accumulation of capital where it had remained incomplete. ${ }^{65}$

It is not so important here to underline that, for Engels, the global history of Civil War projected the United States into "a differed position in world history within the shortest possible time." 66 Rather, it is more relevant to highlight that the state moment of the Civil War allowed Marx to reveal what remained hidden behind the promise of self-rule and happiness that Lincoln saw in the postwar nation; that is, behind the social harmony that Carey intended to scientifically root in the "natural law" of American capitalism. Before the Civil War, Marx himself had recorded the specificity of US society. In the Economic Manuscripts of 1861-1863, he wrote that the abstraction of labor as a "means to create wealth in general" was taken to its highest level for the first time overseas. In the United States, "individuals easily pass from one kind of labour to another" because "the particular kind of labour [is] accidental to them and therefore indifferent." However, this indifference toward work (neither manufacturing, nor mercantile, nor agricultural work, but all types of work) that characterized the independence of producers was nothing more than a historical product of a society where free labor fought against slavery. Instead, independence of labor diminished after the war and the separation of labor from ownership removed the "promised land" 67 of emancipation from wage slavery from the world market:

... the American Civil War brought in its train a colossal national debt, and, with it, pressure of taxes, the rise of the vilest financial aristocracy, the squandering of a huge part of the public land on speculative companies for the exploitation of 
railways, mines, in brief, the most rapid centralization of capital. The great republic has, therefore, ceased to be the promised land for emigrant labourers. Capitalistic production advances there with giant strides, even though the lowering of wages and the dependence of the wage worker are yet far from being brought down to the normal European level. ${ }^{68}$

As Marx would have synthetically underlined also in the preface to the second Russian edition of the Communist Party Manifesto (1882), "step by step the smaller and middle landownership of the farmers, the basis of the whole political constitution, is succumbing to the competition of giant farms; simultaneously, a numerous proletariat and a fabulous concentration of capital are developing for the first time in the industrial regions." ${ }^{69}$ Marx, therefore, theoretically and historically understood not only the new social relations following the Civil War but also the unprecedented political conditions that offered the possibility for emancipation. From a theoretical point of view, since the state moment of the Civil War solved the colonial problem of accumulation, Marx revoked any possibility of appeal to the US political economy. In the $1850 \mathrm{~s}$, he had allowed his rival in the columns of the New York Daily Tribune to be "the only original economist among the North Americans." Carey's attempt "to demonstrate the harmony of the relations of production at the point where the classical economists naively analyzed their antagonism" had "at least the merit of articulating in abstract form the magnitude of American relations and of doing so in contradiction of those of the Old World." For Marx, in fact, US society allowed for an "unprecedented scale and unprecedented conditions of freedom of movement" until the Civil War. The worker could "appropriate a part of his surplus" and "accumulate enough to become a farmer . . . through the reproduction of earlier modes of production and [forms] of property on the bases of capital (e.g. of the independent peasantry)." But, after the Civil War, even in the United States, "the contradictions of bourgeois society" no longer appeared "as transient moments." Consequently, Carey's "harmonious laws" lost that aforementioned merit. His economic school became dogmatic not only because it denied the antagonism between capital and labor, but also because it demanded that the "American dogma" of harmony of interests be valid for the world: "He is American as much in his assertion of the harmony within bourgeois society as in his assertion of the disharmony of the same relations in their world market form." 70

From a historical point of view, these new social relations that marked labor on both sides of the Atlantic opened up new possibilities for emancipation that Marx exalted in his Capital by using the notion of civil war no longer in exclusive reference to the United States but also in reference to his vision of the class struggle. While in a letter to Weydemeyer in 1852, Marx had admitted that the US society was "still far too immature for the class struggle to be made perceptible and comprehensible," in Capital the notion of civil war was used to describe the global history of the class struggle for the working day. In this specific sense, as Dunayevskaya argued, unlike Marx's Economic Manuscripts 
(1857-1858, 1861-1863) where his criticism is brought to an almost exclusively theoretical level, Capital "is proof of the creative impact of masses in motion on theory."71 The US Civil War marked a decisive moment in "a protracted civil war, more or less dissembled, between the capitalist class and the working class:”

In the United States of North America, every independent movement of the workers was paralyzed so long as slavery disfigured a part of the Republic. Labor cannot emancipate itself in the white skin where in the black it is branded. But out of the death of slavery a new life at once arose. The first fruit of the Civil War was the eight hours' agitation, that ran with the seven-leagued boots of the locomotive from the Atlantic to the Pacific, from New England to California. $^{72}$

\section{The Issue of Emancipation as a Global Question}

Before and after the Paris Commune, Marx repeatedly returned to reflect on the labor movement in the United States in interviews given to the US press in New York and Chicago and in writings written on behalf of the International Working Men's Association. This latter moved to New York after 1871, not only to remove it from the anarchist and socialist influence of Europe, but also because of the importance the United States had been gaining in the world market. ${ }^{73}$ From the beginning of the decade it had dozens of branches in different industrial areas of the country, from Boston to San Francisco, passing through New York, Saint Louis, and Chicago. Besides, as Marx wrote in the preface to the first edition of Capital dated July 25, 1867, quoting the words of Benjamin Franklin Wade, a radical Republican firmly against the policies of President Johnson: "after the abolition of slavery, a radical change of the relations of capital and of property in land is next upon the order of the day."74 Within this new agenda, the working-class voices in Europe that during the Civil War had raised the cry against slavery, could not ignore the labor movement in the United States and could not even confine the class struggle to within the racial boundary of white labor. The issue of emancipation needed to be opened to the presence of a Black proletariat: emancipation should face the political problem of slavery, no longer as property but as a principle of racial superiority, determined along the color line that divided the white working class from the Black proletariat. As was written in the International Workingmen's Association message sent to the National Labor Union, the main organization in the United States at that time that led the fight for eight hours, Marx did not forget that the victory against slavery had given an unprecedented "moral impetus" to the "class movement." "The glorious task" that the Civil War bequeathed on both sides of the Atlantic was therefore "to prove to the world" that "the working classes are bestriding the scene of history no longer as servile retainers, but as independent actors." 75 However, from the start this challenge seemed all the more difficult the more global a scene the 
Civil War imposed on the issue of emancipation. Marx wrote to Engels about this already at the end of 1858 :

The proper task of bourgeois society is the creation of the world market, at least in outline, and of the production based on that market. Since the world is round, the colonization of California and Australia and the opening up of China and Japan would seem to have completed this process. For us, the difficult question is this: on the Continent revolution is imminent and will, moreover, instantly assume a socialist character. Will it not necessarily be crushed in this little corner of the earth, since the movement of bourgeois society is still in the ascendant over a far greater area ${ }^{76}$

In conclusion, the importance of reading Marx lies in his theoretical vision of the US Civil War as a "world-historical fact" that materially changed not only US history, but also the history of capitalism because it changed the historical, institutional, and social temporalities in which individuals at work in a racially connoted way experienced democracy, the state, its politics and policy of accumulation, and the world market and its industrial capital. Although skeptical of the national ways to emancipation, up to the Manifesto Marx had thought of emancipation in the political terms of an international alliance of the European proletariat. Between the 1850s and 1860s, in light of the events in the United States, the issue of emancipation could only be tackled at the world-market level. Marx acknowledged that the world market revoked the exclusive character of national histories because it framed individuals as "empirically universal individuals"; that is, the world market framed individuals materially connected by "a power alien to them." In this specific sense, the Civil War for Marx was not just a national war that historically brought to fruition the democratic constitution, marking the triumph of free labor. Nor was it just an international war that allowed capital to take control of US society and lead domestic industry to success in the commercial competition between national economies. Behind these wars, another civil war was raging: A real movement of individuals at work in different and distant points of the world market who, pitting themselves against the power that connected them, determined new social and political conditions that offered the possibility for emancipation. For this reason, reconstructing the history of the Civil War through Marx did not just bring to light a historical contingency in which actors other than the European white working class, to which the Manifesto had entrusted the task of Communism, made their appearance. Marx's global history of the Civil War also, and above all, brought to light his theoretical attempt to think of emancipation as a global issue. In other words, the problem-both historical and theoretical-that his work on the United States left unresolved in the pages of Capital was how to solve the issue of emancipation when it was placed in a world market where the presence of a racially connoted and divided proletariat, the saturation of the democratic movement, and the accumulation policy of the states prevented the identification of a single point 
from which to deploy a new political history of the class struggle. His global history of Civil War was not in this sense "a collection of dead facts," but it was a history of the present. ${ }^{77}$

\section{NOTES}

1. Marx and Engels Collected Works (MECW), 41 (New York, 1985), 4-5. A short version of this essay is published in Matteo Battistini, Maurizio Ricciardi, and Eleonora Cappuccilli (eds.), Global Marx. Storia e critica del movimento sociale nel mercato mondiale (Milano, 2020), 293-314.

2. "Marx to Engels," December 2, 1864, in MECW, 42 (New York, 1987), 49.

3. "Marx to Lion Philips," May 6, 1861, in MECW 41 (New York, 1985), 277. The reference to Manchester's liberalism is in Marx, "The Washington Cabinet and the Western Powers" (written around December 20,1861), in Die Presse, December 25, 1861, in MECW 19 (New York, 1984), 124-126. In several passages of his work, Marx criticized the US political economy through the only figure he thought relevant: that of Henry Carey. In particular, see chapter XXII, "National Differences of Wages" from Capital 1, in MECW 35 (New York, 2010), 563-562; "Economic Manuscripts of 1857-58," in MECW 28 (New York, 1987), 5-16, 499-516. Cf. Michael Perelman, Marx's Crises Theory. Scarcity, Labor and Finance (New York, 1987) 10-26. The English translation of the book (Global Marx: History and Critique of Social Movement in the World Market.) is upcoming for BRILL (Fall 2022).

4. Dawid W. Blight, Race and Reunion. The Civil War in American Memory (Cambridge, MA, 2001); Charles R. Wilson, Baptized in Blood. The Religion of the Lost Cause, 1865-1920 (Athens, GA, 2011).

5. The reference is mainly to the Dunning School in the first half of the twentieth century. The historians of the consensus school from the 1940s and 1950s include, among others: Louis Hartz, The Liberal Tradition in America (New York, 1955) and Daniel J. Boorstin, The Americans (New York, 2 vols., 1958 and 1965). One of the main refutations of historiographical exceptionalism is John Higham, "Beyond Consensus. The Collapse of Consensus History," Journal of American History 76 (1989): 460-466.

6. Richard J.M. Blackett, Divided Hearts. Britain and the American Civil War (Baton Rouge, LA, 2001); Howard Jones, Blue and Gray Diplomacy. A History of Union and Confederate Foreign Relations (Chapel Hill, NC, 2010); Amanda Foreman, A World on Fire. Britain's Crucial Role in the American Civil War (New York, 2011).

7. On the role of slaves in the Civil War, see David Brion Davis, The Problem of Slavery in the Age of Emancipation (New York, 2014); Robin Blackburn, The American Crucible. Slavery, Emancipation, and Human Rights (New York, 2011); Richard Worth, Slave Life on the Plantation (Berkeley Heights, NJ, 2004); Ira Berlin, Generations of Captivity. A History of African American Slaves (Cambridge, MA, 2003); Eric Foner, Forever Free. The Story of Emancipation and the Reconstruction (New York, 2005); Ira Berlin et al. (eds.), Free at Last: A Documentary History of Slavery, Freedom, and the Civil War (New York, 1992); George P. Rawick, From Sundown to Sunup: The Making of the Black Community (Westport, CT, 1973).

On the role of women: Nina Silber, Gender and the Sectional Conflict (Chapel Hill, NC, 2008); Nina Silber, Daughters of the Union. Northern Women Fight the Civil War (Cambridge, MA, 2005); Theresa McDevitt, Women and the American Civil War. An Annotated Bibliography (Westport, CT, 2003).

On the rise of American capitalism and the process of nation-making, see Michael Zakim and Gary J. Kornblith (eds.), Capitalism Takes Command. The Social Transformation of 19th Century America (Chicago, 2012); Heather C. Richardson, The Greatest Nation of the Earth. Republican Economic Policy during the Civil War (Cambridge, MA, 2009); Nicholas Onuf and Peter Onuf, Nations, Markets, and War. Modern History and the American Civil War (Charlottesville, VA, 2006).

On the social and political divisions within the South: David Williams, Bitterly Divided. The South's Inner Civil War (London, 2008); Eugene D. Genovese and Elizabeth Fox-Genovese, Fatal Self-Deception. Slaveholding Paternalism in the Old South (Cambridge, 2011); Robert E. Bonner, 
Mastering America. Southern Slaveholders and the Crisis of American Nationhood (New York, 2009); Lacy K. Ford, Deliver Us from Evil. The Slavery Question in the Old South (Oxford, 2009).

8. "Lincoln Studies at the Bicentennial. A Round Table," Journal of American History 96 (2009): 417-461; Michael E. Woods, "What Twenty-First Century Historians Have Said about the Causes of Disunion. A Civil War Sesquicentennial Review of Recent Literature," Journal of American History 99 (2012): 414-439. On Civil War as a war of nationalization and on its reception in Europe, see Michael Geyer and Charles Bright, "Global Violence and Nationalizing Wars in Eurasia and America. The Geopolitics of War in the Mid-Nineteenth Century," Comparative Studies in Society and History 38(1996): 619-657; Andre M. Fleche, The Revolution of 1861. The American Civil War in the Age of Nationalist Conflict (Chapel Hill, NC, 2012); Don Doyle, The Cause of All Nations. An International History of the American Civil War (New York, 2015); Richard Carwardine and Jay Sexton, eds., The Global Lincoln (Oxford, 2011); Tiziano Bonazzi and Carlo Galli (eds.), La guerra civile americana vista dall'Europa (Bologna, 2004).

On the historical relationship between slavery and capitalism from an international and transnational perspective, see Sven Beckert, Empire of Cotton: A Global History (New York, 2015); Enrico Dal Lago, American Slavery, Atlantic Slavery, and Beyond. The U.S. Peculiar Institution in International Perspective (London, 2012); Zach Sell, Trouble of the World. Slavery and Empire in the Age of Capital (Chapel Hill, 2021); Brian Schoen, The Fragile Fabric of the Union. Cotton, Federal Politics, and the Global Origins of the Civil War (Baltimore, MD, 2009); John Ashworth, Slavery, Capitalism, and Freedom in the Antebellum Republic (Cambridge, 1995); Eric Williams, Capitalism and Slavery (Chapel Hill, NC, 1944). Cf. Charles Post, American Road to Capitalism, 1620-1877: Studies in Class-Structure, Economic Development and Political Conflict (Chicago, 2011); James Oakes, "Capitalism and Slavery and the Civil War," in International Labor and Working-Class History 89 (2016): 195-220.

9. David M. Prior et al., "Teaching the Civil War Era in Global Context: A Discussion," Journal of the Civil War Era 5 (2015): 97-125; Douglas R. Egerton, "Rethinking the Atlantic Historiography in a Post-Colonial Era: The Civil War in a Global Perspective," Journal of the Civil War Era 1 (2011): 75-79.

10. Daniel T. Rodgers, The Age of Fracture (Cambridge, MA, 2003).

11. Sven Beckert and Seth Rockman, Slavery's Capitalism. A New History of American Economic Development (Philadelphia, PA, 2016), 6-13.

12. Marx, "Address of the International Workingmen's Association. To Abraham Lincoln, President of the United States of America" (written between November 22 and 29, 1864), The Daily News, December 23, 1864, in MECW 20 (New York, 1985), 19-21. Marx can be considered the main author of the address.

13. "The 1619 Project," The New York Time Magazine: https://www.nytimes.com/interactive/2019/08/14/magazine/1619-america-slavery.html See in particular Matthew Desmond, "In order to understand the brutality of American capitalism, you have to start on the plantation," in The New York Time Magazine, August 14, 2019. Cf. Adam Serwer, "The Fight Over the 1619 Project Is Not About the Facts," in The Atlantic, December 23, 2019: https://www.theatlantic. com/ideas/archive/2019/12/historians-clash-1619-project/604093/

14. "Marx to Engels," November 23, 1869, in MECW 43 (New York, 1988), 385. On the ideology of free labor, the Lincoln vision of American development and the unintended economic and social consequences of the Civil War, see Eric Foner, Free Soil, Free Labor, Free Men: The Ideology of the Republican Party before the Civil War (New York, 1970), 29-30 and Tiziano Bonazzi, Abraham Lincoln. Un dramma americano (Bologna, 2016), 292-296. On Carey, see Matteo M. Rossi, "Protecting America: Order, Nation and Exception in Henry Carey's Social Science," USAbroad. Journal of American History and Politics 2 (2019): https://usabroad.unibo.it/article/view/8542/8840; Andrew Dawson, "Reassessing Henry Carey (1973-1879): The Problems of Writing Political Economy in NineteenthCentury America," Journal of American Studies 34 (2000): 465-485.

15. Marx, Comments on the North American Events (written on October 7, 1862), in Die Presse, October 12, 1862, in MECW 19, 250-251. About Carey and his attempt to deny the antagonistic character not only of the relationship between the capitalist and waged worker but also of the slave system: Marx, Capital 1, in MECW 35, 533 and 737. 
16. Eugene Genovese, In Red and Black: Marxian Explorations in Southern and AfroAmerican History (New York, 1971), 315-353. Cf. Doyle, The Cause of All Nations, 150-155; Carwardine and Sexton (eds.), The Global Lincoln, 85-89.

17. See Andrew Zimmerman's extensive introduction to Karl Marx and Friedrich Engels, The Civil War in the United States (New York, 2016). Marx's writings on the Civil War are not considered or are simply quoted but not discussed, in recent historiographical works that deal with the historical relationship between slavery, capitalism, and the American state from an international and transnational perspective: Beckert and Rockman (eds.), Slavery's Capitalism; Beckert, Empire of Cotton; Zakim and Kornblith, Capitalism Takes Command, 119-120; Dal Lago, American Slavery, Atlantic Slavery, and Beyond; Schoen, The Fragile Fabric of the Union; Richardson, The Greatest Nation of the Earth; Onuf and Onuf, Nations, Markets, and War; Ashworth, Slavery, Capitalism, and Freedom, vol. 1, 82-83, 95-96, 155-156, vol. 2, 5, 176.

18. The only exception is The Karl Marx Library vol. 2, edited by Saul K. Padover (197277), although not completely exhaustive.

19. Under the alias J.R. Johnson, James mentioned Marx and the Civil War in "The Revolution and the Negro," New International, V (December 1939), 339-343. See also James, "Negroes in the Civil War: Their Role in the Second American Revolution," New International, 11 (1943), 338-42. Raya Dunayevskaya, Marxism and Freedom [1958] (New York, 2000), 81-91.

20. W.E.B. Du Bois, "The Negro and Communism," in The Crisis 38 (September 1931), reprinted in Eric J. Sundquist (ed.), The Oxford W.E.B. Du Bois Reader (New York, 1996), 400-409. Cf. David Levering Lewis, W.E.B. Du Bois. The Fight for Equality and the American Century 1919-1963 (New York, 2000), 199-203; Marable, W.E.B. Du Bois: Black Radical Democrat (London, 2005), 137. Marx had written: "Labor cannot emancipate itself in the white skin where in the black it is branded," in Marx, Capital 1, 305.

21. Herbert M. Morais (ed.), The Civil War in the United States: Karl Marx and Frederick Engels (New York, 1937); Saul K. Padover (ed.), Karl Marx on America and the Civil War (New York, 1972). See the bibliographic essay in Allan Kulikoff (ed.), Abraham Lincoln and Karl Marx in Dialogue (Oxford, 2018); and the introductory essay Robin Blackburn (ed.), Marx and Lincoln. The Unfinished Revolution (New York, 2011); see also Blackburn, The American Crucible, 315-316, 416-417, 420. For a bibliographic review of Marx in the United States, see Robert Wiene, "Karl Marx's Vision of America: A Biographical and Bibliographical Sketch," The Review of Politics 42 (1980):s 465-503.

22. This point is discussed by recent Marxist literature: Kevin B. Anderson, Marx at the Margins: on Nationalism, Ethnicity, and Non-Western Societies (Chicago, 2010), 79-114; Tom Jeannot, "Marx, Capitalism, and Race," Radical Philosophy Today 5 (2007): 69-92; Gerald A. Cohen, Karl Marx's Theory of History: A Defence (Oxford, 1978), 65-73, 88-92, 199-202; Robert Miles, Capitalism and Unfree Labour: Anomaly or Necessity? (London, 1987). See also August H. Nimtz, "Marx and Engels on the US Civil War: The "Materialist Conception of History' in Action," Historical Materialism 19 (2011): 169-192; Nimtz, Marx, Tocqueville, and Race in America. The "Absolute Democracy" or "Defiled Republic" (Lanham, 2003).

23. Cf. Anderson, Marx at the Margins, 79-80, 110; David R. Roediger, Seizing Freedom: Slave Emancipation and Liberty for All (New York, 2014), 11-12; Cedric Robinson, Black Marxism (Chapel Hill, NC, 2000), 81, 113-120.

24. Marx, "Provisional Rules of the Working Men's International Association," November 1864, MECW 20, 14.

25. Marx, "The Poverty of Philosophy," in MECW 6 (New York, 1976), 167. Cf. "Marx to Pavel Vasilyevich Annenkov," December 28, 1846, in MECW 38 (New York, 1982), 101-102.

26. Marx, "Economic Manuscripts of 1857-58," 157; "Wage Labor and Capital" [1849], in MECW 9 (New York, 1977), 211. As Kevin B. Anderson has recently argued, Marx did not view the large-scale enslavement of Africans by Europeans as a repeat of Roman or Arab slavery, but as something new that was strictly connected to the rise of industry. Kevin B. Anderson, "What Marx Understood About Slavery," in Jacobin Magazine, September 5, 2019: https:// www.jacobinmag.com/2019/09/slavery-united-states-civil-war-marx. For a different perspective that does not aim to redeem Marx by expanding his view of race, but that aims to alter his theoretical framework on slavery by following the critical stand of Frank B. Wilderson III, see SaraMaria Sorentino, "The Abstract Slave: Anti-Blackness and Marx's Method," in International Labor and Working-Class History 96 (2019): 17-37. Cf. Frank B. Wilderson III, "Gramsci's Black Marx: Whither the Slave in Civil Society?" Social Identities 9 (2003): 225-40. 
27. Marx, Capital 3 (New York, 2010), 382. Cf. Marx, Capital 1, 337. Cf. James Edward III Ford, "From Being to Unrest, from Objectivity to Motion: The Slave in Marx's Capital," Rethinking Marxism 23 (2011): 22-30

28. Marx, "The British Cotton Trade" (written September 21, 1861), in The New York Daily Tribune (NYDT), October 14, 1861, in MECW 19, 20.

29. Marx, "Notes on Thomas Buxton [1851]," in Marx-Engels Gesamtausgabe, vol. IV/9 (Berlin, 1991), 494-501. Cf. Kevin B. Anderson, "Marx's intertwining of race and class during the Civil War in the United States," in Journal of Classical Sociology 17 (1): 28-40; Lucia Pradella, Globalization and the Critique of Political Economy. New Insights from Marx's Writings (London, 2014), 111.

30. Marx, "English Public Opinion" (written on January 11, 1862), in NYDT, February 1, 1862, in MECW 19, 137. In another article dated September 21, 1861, he stressed the importance that two other interests had in preventing a military intervention by the Palmerston government to free the South from the Northern naval blockade: "the monetary interest having sunk an immense capital in the industrial enterprises of Northern America, and the corn trade, relying on Northern America as its principal source of supply." Marx, "The British Cotton Trade," 18.

31. Marx, "The London Times on the Orleans Princes in America" (written October 12, 1861), in NYDT, November 7, 1861, in MECW 19, 30.

32. Marx, On the Jewish Question, in MECW 3, 150-155; the writings of Marx on the insurrections of 1848 in France, Germany, Poland, Belgium, and Italy, and on Chartism in Great Britain, are collected in MECW 6-9.

33. W.E.B. Du Bois, "To the Nations of the World," remarks given on July 25, 1900, at the first Pan African Convention, London. Marx's and Du Bois's writings have been essential for the historiographical understanding of the historical relation between class and race in the United States, cf. David R. Roediger, The Wages of Whiteness. Race and the Making of the American Working Class, London, 1991, 11-13, 166-169; Roediger, Seizing Freedom, 11-12.

34. Blackburn, Marx and Lincoln, 56-58; Lucia Pradella, "Crisis, Revolution and Hegemonic Transition: The American Civil War and Emancipation in Marx's Capital," in Science \& Society 80 (2016): 454-467; Hal Draper, "The Principle of Self-Emancipation in Marx and Engels," Socialist Register, 1971: 81-109, available at socialistregister.com.

35. Bruce Levine, The Spirit of 1848: German Immigrants, Labor Conflict and the Coming of the Civil War (Urbana, IL, 1992).

36. Michael Perelman, Political Economy and the Press: Karl and Henry Carey at the New York Tribune: https://michaelperelman.wordpress.com/2008/05/19/political-economy-andthe-press-karl-marx-and-henry-carey-at-the-new-york-tribune/.

37. Marx, "The North American Civil War" (written on October 20, 1861), in Die Press, October 25, 1861, in MECW 19, 32.

38. Marx, "English Public Opinion," 137-142. See also in MECW 19: Karl Marx, "The American Question in England" (written September 18, 1861), in NYDT, October 11, 1861; "The London Times on the Orleans Princes in America;" and "Intervention in Mexico" (written November 7, 1861), in NYDT, November 23, 1861; "The British Cotton Trade." Cf. Karl Marx, "The North American Civil War" (written on October 20, 1861), in Die Press, October 25, 1861, in MECW 19, 32; "The Crisis in England" (written November 2, 1861), in Die Presse, November 7, 1861; "The Trent Case" (written on November 28, 1861), in Die Presse, December 2, 1861; "The Washington Cabinet and the Western Powers;" and "On the Cotton Crisis" (written in early February 1862), in Die Presse, February 8, 1862; "The Parliamentary Debate on the Address" (written on February 7, 1862), in Die Presse, February 12, 1862; "The Secessionists' Friends in the Lower House-Recognition of the American Blockade" (written on March 8, 1862), in Die Presse, March 12, 1862; "English Neutrality-The Situation in the Southern States" (written on November 29, 1862), in Die Presse, December 4, 1862.

39. Marx, "The Civil War in the United States" (written November 1,1861), in Die Presse, November 6, 1861, in MECW 19, 50; "The North American Civil War," 37-38. Cf. Marx, "The American Question in England," 7-16.

40. Gerald Runkle, "Karl Marx and the American Civil War," Comparative Studies in Society and History 6 (1964): 117-141.

41. Marx, "Economic Manuscripts of 1861-1863," in MECW 31 (New York, 1989), 516; Marx, Capital 1, Chapter VIII, "The Working Day," 272. 
42. Marx, "The North American Civil War," 39-40; "Marx to Engels," July 1, 1861, in MECW 41, 301.

43. "Marx to Engels," July 1, 1861; "Marx to Engels," July 5, 1861, in MECW 41, 300-303, 305-309. A little less than a year later, in a crucial phase of the war, Marx noted that "the white trash, as the planters themselves call the 'poor whites', will attempt guerilla warfare and brigandage. Such an attempt, however, will very quickly transform the propertied planters into Unionists. They will even call the Yankee troops to their aid." Marx, "The Situation in the American Theatre of War" (written on May 23-25, 1862), in Die Presse, May 30, 1862, in MECW 19, 207.

44. Marx, "The North American Civil War," 41.

45. Marx, "The Civil War in the United States," 43, 49-50. Cf. "Marx to Engels," September 10, 1862, in MECW 41, 415-416.

46. Marx, "The American Question in England," 9.

47. "Marx to Lion Philips," 277.

48. Marx, "A Criticism of American Affairs" (written in early August 1862), in Die Presse, August 9, 1862, in MECW 19, 228. Cf. "Marx to Engels," July 30, 1862, "Marx to Engels," August 7, 1862, in MECW 41, 388-390, 399-401. Cf. Roediger, Seizing Freedom, 68.

49. W.E.B. Du Bois, Black Reconstruction in America, 1935, Chapter IV: "The General Strike."

50. Marx, "The Situation in North America," 257-258.

51. Marx, "The Civil War in the United States;" "The Dismissal of Frémont" (written about November 19, 1861), in Die Presse, November 26, 1861; "The Crisis over the Slavery Issue" (written on December 10, 1861), in Die Presse, December 11, 1861; "A Pro-America Meeting" (written on January 1,1862), in Die Presse, January 5, 1862; "American Affairs" (written in late February 1862), in Die Presse, March 3, 1862; "The American Civil War" (written on March 7 and 22, 1862), in Die Presse, March 26, 1862; "The Situation in the American Theatre of War;" "A Criticism of American Affairs;" "Abolitionist Demonstrations in America" (written on August 22, 1862) in Die Presse, August 30, 1862; "The Dismissal of McClellan" (written on November 24, 1862), in Die Presse, November 29, 1862. In MECW 19, 50-51, 115-116, 179, 186-195, 204-208, 227-228, 233-235, 266-269.

On the antislavery movement and President Lincoln's political and military decisions, see E. Foner, The Fiery Trial: Abraham Lincoln and American Slavery (New York, 2010).

52. Marx, "The Opinion of the Newspapers and the Opinion of the People" (written on December 25, 1861), in Die Presse, December 31, 1861; "A Pro-America Meeting" (written on January 1,1862), in Die Presse, January 5, 1862; "A Coup d'État by Lord John Russell" (written on January 16-17, 1862), in Die Presse, January 21, 1862; "English Public Opinion" (written on January 11, 1862), in NYDT, February 1, 1862; "A London Workers' Meeting" (written on January 28, 1862), in Die Presse, February 2, 1862; "Anti-Intervention Feeling" (written on January 31, 1862), in Die Presse, February 4, 1862. In MECW 19, 128, 135, 138142, 146, 153-154, 157-159. In "The Situation in North America" Marx notes that during 1862 "Europe supplied the United States with an emigrant contingent of approximately 100,000 souls and that half of these emigrants consist of Irishmen and Britons." In MECW 19, 259. Workers' meetings continued in the early months of 1863: "Marx to Engels," January 2, 1863 and "Marx to Engels," April 9, 1863, in MECW 41, 439-441, 466-469. On the role played by the working class in Great Britain during the Civil War and the role of Marx in organizing workers' meetings to sustain the North and the abolition of slavery, see Philip S. Foner, British Labor and the American Civil War, New York, 1981, particularly 11-13, 57-62, 93-94.

53. Marx did not note that the granted land was largely Native Americans' land. "Marx to Engels," July 1, 1861, 300; "The North American Civil War," 32-42; "The American Civil War I" (written on March 7, 1862), in Die Presse, March 26, 1862; "A Criticism of American Affairs;" "Abolitionist Demonstrations in America." In MECW 19, 42, 188, 228, 233-235. See also the correspondence between Marx and Engels from 12 May to 10 September 1862, in MECW 41, 363-417. Marx is aware of the American workers' and social reformers' struggles of the 1830s and 1840s for the free distribution of frontier lands, see Blackburn, An Unfinished Revolution, 2.

54. Marx, "Comments on the North American Events," 250. According to Marx, the compulsory military conscription in the Confederacy showed the difficulties in recruiting troops and the exhaustion of military resources. Above all, the tensions between the Confederate states showed that "the doctrine of the 'states' rights, (the sovereignty of states), with which the 
usurpers in Richmond gave the secession a constitutional colouring, is already beginning to turn against itself. That is how little Mr. Jefferson Davis has succeeded in 'making a nation of the South' as his English admirer Gladstone boasted." In "Symptoms of Disintegration in the Southern Confederacy" (written on November 7, 1862), in Die Presse, November 14, 1862, in MECW 19, 262.

55. Marx, "The Election Results in the Northern States" (written on November 18, 1862), in Die Presse, November 23, 1862, in MECW 19, 264. See also the correspondence between Engels and Marx from October 29, 1862 to September 7, 1864, in MECW 41, 419-562.

56. Marx, "To Abraham Lincoln, President of the United States of America" (written between November 22 and 29, 1864), in MECW 20, 19-21. "Marx to Engels," February 10, 1865, in MECW 42 (New York, 1987), 86.

57. See the correspondence between Marx and Engels from 4 March 1865 to 23 April 1866, in MECW 42, 114-269; Marx, To Abraham Lincoln, 19-21. See also the Address from the Working Men's International Association to President Johnson, in MECW 20, 99-100.

58. Marx, To Abraham Lincoln, 20; Address from the Working Men's International Association to President Johnson, 100.

59. In two interviews granted in the New York newspaper World on July 18, 1871, and in the Chicago Tribune on January 5, 1879, Marx pointed his finger at the cowardice of the European, English, German and American middle classes when talking about their reaction to the workers' movement in terms of a slaveowners' war. In Philip S. Foner (ed.), Karl Marx Remembered (San Francisco, 1973), 240-262. He defined the revolution of 1776 as a middle-class revolution in the "Preface to the first German edition" of the Capital, 33.

60. Note by Engels in Capital 1, 454-455.

61. Marx, Capital 1, Chapter XXXIII, "The Modern Theory of Colonization," 751-764; "Marx to Engels," November 19, 1869, in MECW 43 (New York, 1985), 377-383.

62. "Marx to Engels," May 27, 1862; "Engels to Marx," October 16, 1862, in MECW 41, 369-370, 419-421.

63. Marx, Capital 1, 742-744.

64. Ibid, 738-739, 744-745.

65. Ibid, 747-748, 759-760.

66. "Engels to Weydemeyer," November 24, 1864, in MECW 42, 39.

67. Marx, "Economic Manuscripts of 1857-58," 41.

68. K. Marx, Capital 1, 760.

69. K. Marx-F. Engels, Preface to the Second Russian Edition of the Manifesto of the Communist Party (written on January 21, 1882), in MECW 24, 425-426.

70. Marx, "Economic Manuscripts of 1857-58," 6-10, 500. "Marx to Joseph Weydemeyer," March 5, 1852, in MECW 39 (New York, 1983), 62; "Marx to Engels," November 19, 1869, in MECW 43, 377-383.

71. Dunayevskaya, Marxism and Freedom, 81; Cf. John F. Welsh, "Reconstructing Capital: The American Roots and Humanist Vision of Marx's Thought," Midwest Quarterly 43 (2002): 274-287; Andrew Zimmerman, Marxism, the Popular Front, and the American Civil War, in Gregory P. Downs and Kate Masur (eds.), The World the Civil War Made (Chapel Hill, NC, 2015), 304-336.

72. Marx, Capital 1, 303, 305. Cf. "Marx to Joseph Weydemeyer," March 5, 1852, 62.

73. Please refer to the two interviews that Marx gave to the World in New York on July 18, 1871 and to the Tribune in Chicago on January 5, 1879, Foner (ed.), Karl Marx Remembered, 240-262.

74. Marx, Capital 1, 11.

75. "Address to the National Labor Union of the United States," May 12, 1869, in MECW 21 (New York, 1985), 54. On the labor movement in the United States for eight hours, the relation between black and white workers and the role of the First International, see David R. Roediger and Philip S. Foner, Our Own Time. A History of American Labor and the Working Day (New York, 1989), 112-144; Roediger, The Wages of Whiteness, 168-169; Roediger, Seizing Freedom, 112-113; Foner, British Labor and the American Civil War, 113114; David Montgomery, Beyond Equality: Labor and the Radical Republicans 1862-1872 (New York, 1967), 296-334.

76. "Marx to Engels," October 8, 1858, in MECW 40 (New York, 1983), 347.

77. Marx and Engels, "The German Ideology," in MECW 5 (New York, 1975), 43-53. 